\title{
Article
}

\section{Effectiveness of ACTH in Patients with Infantile Spasms}

\author{
Justyna Paprocka ${ }^{1, *}$, Jakub Malkiewicz ${ }^{2} @$, Veronica Palazzo-Michalska ${ }^{3}$, Barbara Nowacka ${ }^{3}$, Mikołaj Kuźniak ${ }^{3}$ \\ and Ilona Kopyta ${ }^{1}$ (1)
}

1 Department of Pediatric Neurology, Faculty of Medical Sciences in Katowice, Medical University of Silesia, 40-752 Katowice, Poland; ilonakopyta@autograf.pl

2 Department of Neurology, Faculty of Medical Sciences in Katowice, Medical University of Silesia, 40-752 Katowice, Poland; jjmalkiewicz@onet.pl

3 Students' Scientific Society, Department of Pediatric Neurology, Faculty of Medical Sciences in Katowice, Medical University of Silesia, 40-752 Katowice, Poland; ver.palazzo@gmail.com (V.P.-M.); b.m.w.nowacka@gmail.com (B.N.); mikolajkuz@wp.pl (M.K.)

* Correspondence: jpaprocka@sum.edu.pl

check for updates

Citation: Paprocka, J.; Malkiewicz, J.; Palazzo-Michalska, V.; Nowacka, B.; Kuźniak, M.; Kopyta, I. Effectiveness of ACTH in Patients with Infantile Spasms. Brain Sci. 2022, 12, 254. https://doi.org/10.3390/ brainsci12020254

Academic Editor: Jesus Pastor

Received: 13 December 2021

Accepted: 7 February 2022

Published: 11 February 2022

Publisher's Note: MDPI stays neutral with regard to jurisdictional claims in published maps and institutional affiliations.

Copyright: () 2022 by the authors Licensee MDPI, Basel, Switzerland. This article is an open access article distributed under the terms and conditions of the Creative Commons Attribution (CC BY) license (https:// creativecommons.org/licenses/by/ $4.0 /)$.

\begin{abstract}
Background: West syndrome is a severe, refractory, epileptic syndrome that usually appears in infancy or early childhood. ACTH is one of the more effective drugs for treating this condition. (2) Aim of the study and methods: The objective of our study was to examine short-term efficacy (during treatment schedule) and long-term outcome of intramuscular $0.02 \mathrm{mg} / \mathrm{kg} / \mathrm{day}$ ACTH (tetracosactide) depot, used concomitantly with other antiepileptic drugs (AEDs) in patients with infantile spasms who did not achieve seizure cessation or relapse when taking only the AEDs. The drug efficacy was evaluated in retrospective and prospective analyses of 50 patients diagnosed with infantile spasms. (3) Results: Complete cessation of spasms was achieved in 42 cases (84\%). EEG improvement was seen in $41(82 \%)$ patients who responded to ACTH therapy. Information on the clinical course of 28 patients was obtained duringlong-term follow-up. In 17 (60.7\%) cases, seizures were still present. Normal or near-normal development was observed in 11 out of 28 children (39\%). ACTH used concomitantly with other AEDis a highly effective treatment with acceptable side effects. (4) Conclusion: Randomized controlled clinical trialswith long-term follow-up are needed to compare the effectiveness of ACTH in polytherapy and monotherapy. Dyskinesias as a potential side effect observed in our study group should be investigated in the following studies.
\end{abstract}

Keywords: West syndrome; infantile spasms; treatment; ACTH; tetracosactide; vigabatrin

\section{Introduction}

Infantile spasms (IS) is a challenging epileptic syndrome to treat. Its incidence is approximately from 1:4000 to 1:6000 live births [1], constituting 13-14.5\% of all cases of infantile epilepsies [2]. It can also be called infantile epileptic encephalopathy since the continuous, disorganized, and arrhythmic electrical activity of neuronal networks may influence brain maturation, cause arrest or regression of previously gained functions, or make infant milestones impossible to achieve [2]. Infantile spasms consist of three features: epileptic spasms, developmental arrest or regression, and hypsarrhythmia-an interictal EEG pattern. However, not all of them must be present. Hypsarrhythmia together with epileptic spasms in clusters are obligatory features to diagnose West syndrome (WS), according to the West Delphi Proposal, but some studies use the terms West syndrome and infantile spasms as synonyms. Neurodevelopmental arrest or regression before the onset of spasms is not required for the diagnosis of WS by the aforementioned Proposal [3]. This epileptic disorder occurs most frequently within 12 months of life, with a peak between 4 and 7 months. However, cases with later onset have been reported [4].

Epileptic spasms are brief contractions (flexions, extensions, or mixed) of the neck, trunk, and upper and lower limbs or head nodding, occurring in clusters, frequently on 
awakening. They last about 1-2 s and are followed by a tonic phase lasting up to $10 \mathrm{~s}[3,5]$. Their origin is either focal, generalized, or both; thus, they can have a symmetrical or asymmetrical form. Subtle spasms may also occur in the course of this condition. They are easily overlooked and take the form of yawning, gasping, eye deviation, facial grimacing, or focal motor activity. They are associated with hypsarrhythmia [3]. Although the definition of hypsarrhythmia has not been established by the West Delphi Proposal [3], some authors define it as an interictal EEG pattern, which is characterized by continuous, asynchronic, disorganized background of high-amplitude, slow waves and coexisting multifocal spikes, polyspikes, sharp waves, and spike-waves [6]. Hypsarrhythmia is not always present in patients suffering from infantile spasms, and it can be modified/atypical depending on the stage of brain development and physiologic situations, such as sleep/wakefulness, treatment with AED, and etiology [6].

Classifications regarding etiology have been established, including the 1989 International League Against Epilepsy division into two subgroups: symptomatic and cryptogenic [7]. The first one means that etiology is known, or previous signs of brain damage, such as psychomotor retardation, neurologic signs, radiologic signs, or other types of seizures, have been present. The latter one means that signs of previous brain damage have been absent, and etiology has not been identified during medical examinations [7]. Many studies prove that cryptogenic patients have a better response to ACTH treatment, and their neurodevelopmental outcome is also more favorable [5,8-12]. Nowadays, according to the ILAE 2017 classification, etiologies are more precisely divided into structural, infectious, genetic, metabolic, immune, and unknown [13].

$\mathrm{ACTH}$, vigabatrin, and corticosteroids are effective and commonly used in infantile spasms [4,14]. There are also some limited data about other non-standard treatment options, such as topiramate, levetiracetam, zonisamide, sodium valproate, benzodiazepines, pyridoxine, and dietary treatments, which seem to be especially promising for topiramate and ketogenic diet $[4,14,15]$. On the other hand, using non-standard therapies as a first-line treatment was associated with worse response rate [16,17]. There is also evidence that shorter lead time to effective treatment results in better developmental outcome $[9,11]$.

The aim of the study was to assess the short-term efficacy (during treatment schedule) and long-term outcome of intramuscular $0.02 \mathrm{mg} / \mathrm{kg} /$ day ACTH (tetracosactide) depot, used concomitantly with other antiepileptic drugs in patients with infantile spasms who did not achieve seizure cessation or relapse when taking only the AEDs.

\section{Materials and Methods}

\subsection{Patient's Characteristics}

Fifty children (29 male, 21 female) diagnosed with infantile spasms were included in the study. The age at the onset of epileptic spasms varied between 1 and 11 months, while the mean was $5.2 \pm 2.2$ months. The age at the onset of ACTH therapy was $8.6(6-9)$ months. According to the ILAE classification, 41 (82\%) patients could be classified as symptomatic. A detailed presentation of patients with known etiology is shown in Table 1. Other types of seizures prior to the onset of epileptic spasms were present in 17 (34\%) patients, and developmental delay was observed during hospitalization in 45 children $(90 \%$, the first developmental evaluations were performed at onset in hypsarrhythmic state), microcephaly in $13(26 \%)$, and dysmorphic features in 17 (34\%). The family history was relevant in the case of $10(20 \%)$ patients. Ten $(20 \%)$ patients were born preterm. Abnormalities in MRI were present in 35 cases $(70 \%)$.

\subsection{Study Pattern}

This study was conducted by a retrospective and prospective analysis of patients hospitalized in the Department of Pediatric Neurology of the Medical University of Silesia in Katowice diagnosed with infantile spasms who were admitted between March 2009 and September 2017. Table 2 shows the onset of epilepsy depending on presence or absence of hypsarrhythmia. Patients who were not treated with ACTH were excluded from the study. 
ACTH was not the first-line treatment in this population and was used concomitantly with other antiepileptic drugs. AEDs taken by the participants of the study during and before the onset of tetracosactide therapy were noted. Tetracosactide was used at a dose of $0.02 \mathrm{mg} / \mathrm{kg} / \mathrm{d}$ for two weeks and tapered to zero over the next 4 or 6 weeks-the exact treatment schedule is presented in Section 3 (Table 3). Patients with treatment lasting 6 weeks had the same schedule without the last 2 weeks with one dose per week. The time of ACTH administration was shortened to 5 weeks in one patient because she was qualified for the neurosurgical operation of hypothalamic hamartoma.

Table 1. Epilepsy etiology.

\begin{tabular}{|c|c|c|c|}
\hline \multicolumn{4}{|c|}{ Etiology } \\
\hline & Structural & Genetic & Metabolic \\
\hline- & $\begin{array}{l}15(50 \%) \text { hypoxic-ischemic } \\
\text { encephalopathy } \\
8(16 \%) \text { cerebral malformation } \\
1(2 \%) \text { hypothalamic hamartoma and } \\
\text { cerebral malformation } \\
1(2 \%) \text { postinfectious changes }\end{array}$ & $\begin{array}{ll}- & 4(8 \%) \text { tuberous sclerosis } \\
\text { - } & 2(4 \%) \text { CDKL5 mutation } \\
\text { - } & 1(2 \%) \text { neurofibromatosis type, } 1 \\
\text { - } & 1(2 \%) \text { microdeletion } 2 q 24.4 \\
\text { - } & 1(2 \%) \text { SPTAN mutation } \\
- & 1(2 \%) \text { CHD2 mutation } \\
\text { - } & 1(2 \%) \text { ARX1 mutation } \\
\text { - } & 1(2 \%) \text { STXBP1 mutation }\end{array}$ & $\begin{array}{l}\text { - } 3(6 \%) \text { mitochondrial diseases } \\
\text { - } 1(2 \%) \text { nonketotic } \\
\text { hyperglycinemia }\end{array}$ \\
\hline
\end{tabular}

Table 2. Epilepsy onset: 2 days-11 months.

\begin{tabular}{cc}
\hline \multicolumn{2}{c}{ Mean Age of the Patients at the First Seizures (months) } \\
\hline Patients with hypsarrhythmia & $5.5 \mathrm{SD}=2.3$ \\
\hline Patients without hypsarrhythmia & $3.3 \mathrm{SD}=2.0$ \\
\hline Study group & $4.6 \mathrm{SD}=2.1$ \\
\hline
\end{tabular}

Video EEG was taken in all patients. Video EEG and EEG were performed at two-week intervals and after the end of ACTH treatment. Improvement of EEG recording in patients with hypsarrhythmia meant its withdrawal and, in other cases, reduction of paroxysmal changes and their amplitude and the dominance of slow theta and delta waves.

Table 3. Schedule of treatment shows frequency of $0.02 \mathrm{mg} / \mathrm{kg} / \mathrm{d}$ ACTH administration in particular weeks of treatment.

\begin{tabular}{cc}
\hline Weeks of Treatment & Frequency of Administration \\
\hline $1-2$ & Every day \\
\hline $3-4$ & Every second day \\
\hline $5-6$ & 2 times in a week \\
\hline $7-8$ & Once in a week \\
\hline
\end{tabular}

As far as the causes of epilepsy are concerned, patients were categorized according to the 2017 ILAE classification as structural, genetic, infectious, metabolic, immune, and unknown. Some patients could be classified into more than one category. The primary clinical outcome was cessation of spasms, defined as the lack of observed seizures until the 14th day of ACTH treatment, and a seizure-free interval during hospitalization. Patients who achieved cessation of epileptic spasms did not have seizures for 28 consecutive days or more from the last witnessed seizure.

\subsection{Statistical Analyses}

Continuous variables were expressed as the mean \pm standard deviation or median (lower quartile-upper quartile), when distribution was not normal. Shapiro-Wilk test and 
Q-Q plots were used to test normality. Categorical variables were presented as numbers and percentages using Open Office (Apache Open Office 4.1.2 Copyright 2015 The Apache Software Foundation). Continuous data were compared by means of the Mann-Whitney $\mathrm{U}$ test. To compare the categorical variables in the short- and long-term outcome, the chisquare test with Yates's correction and Fisher's exact probability test were used, respectively. The data were compared using Statistica 12 (Tulusa, OK, USA). Statistical significance was defined as $p<0.05$.

\subsection{Treatment Schedule}

All patients took at least one AED prior to tetracosactide, and they did not achieve cessation of spasms or had recurrence of epileptic spasms when they started ACTH therapy. The time from diagnosis of epilepsy to administration of the first AED was longer than 30 days in 7 symptomatic patients. The average time lag between the onset of epileptic spasms and the beginning of ACTH therapy was 1.5 (1-3) months. ACTH was used with many other AEDs as add-on therapy. The median number of drugs used prior to tetracosactide was $3.66 \pm 1.85$ (Table 4 ). Some patients were undergoing discontinuation of other AEDs when they started ACTH therapy. The following drugs were used during the first two weeks of ACTH therapy:valproate in 41 (82\%) patients, vigabatrin in 36 patients, levetiracetam in 9 patients, clobazam in 8 patients, clonazepam in 4 patients, phenobarbital in 2 patients, lamotrigine in 2 patients, and topiramate in 2 patients. The mean number of drugs used during ACTH treatment was 2.06.

Twenty-five (50\%) patients used the two most common drugs-both vigabatrin and valproic acid at the same time. During the whole period of ACTH therapy, the children were hospitalized.

Table 4. Antiepileptic drugs used before the onset of ACTH.

\begin{tabular}{cccc}
\hline Antiepileptic Drugs & $\begin{array}{c}\text { Patients with } \\
\text { Hypsarrhythmia }\end{array}$ & $\begin{array}{c}\text { Patients without } \\
\text { Hypsarrhythmia }\end{array}$ & Study Group \\
\hline Vigabatrin & $\mathrm{N}=22(92 \%)$ & $\mathrm{N}=14(82 \%)$ & $\mathrm{N}=36(88 \%)$ \\
\hline Valproic acid & $\mathrm{N}=22(92 \%)$ & $\mathrm{N}=15(88 \%)$ & $\mathrm{N}=37(90 \%)$ \\
\hline Levetiracetam & $\mathrm{N}=5(21 \%)$ & $\mathrm{N}=9(52 \%)$ & $\mathrm{N}=14(34 \%)$ \\
\hline Clobazam & $\mathrm{N}=5(21 \%)$ & $\mathrm{N}=8(47 \%)$ & $\mathrm{N}=13(31 \%)$ \\
\hline Phenobarbital & $\mathrm{N}=3(13 \%)$ & $\mathrm{N}=6(35 \%)$ & $\mathrm{N}=9(22 \%)$ \\
\hline Clonazepam & $\mathrm{N}=3(13 \%)$ & $\mathrm{N}=3(18 \%)$ & $\mathrm{N}=6(15 \%)$ \\
\hline Carbamazepine & $\mathrm{N}=0$ & $\mathrm{~N}=3(18 \%)$ & $\mathrm{N}=3(7 \%)$ \\
\hline Lamotrigine & $\mathrm{N}=1(4 \%)$ & $\mathrm{N}=2(12 \%)$ & $\mathrm{N}=3(7 \%)$ \\
\hline Phenytoin & $\mathrm{N}=0$ & $\mathrm{~N}=2(12 \%)$ & $\mathrm{N}=2(5 \%)$ \\
\hline Topiramate & $\mathrm{N}=2(8 \%)$ & $\mathrm{N}=1(6 \%)$ & $\mathrm{N}=2(5 \%)$ \\
\hline Acetazolamide & $\mathrm{N}=1(4 \%)$ & $\mathrm{N}=1(6 \%)$ & $\mathrm{N}=1(2 \%)$ \\
\hline Nitrazepam & $\mathrm{N}=0$ & $\mathrm{~N}=1(6 \%)$ & $\mathrm{N}=1(2 \%)$ \\
\hline
\end{tabular}

\section{Results}

Complete cessation of spasms was achieved in 42 cases out of 50 children (84\%) withcombined antiepileptic therapy (ACTH and AEDs). Among children who responded to ACTH, 20 were with hypsarrhythmia. EEG improvement was seen in 41 (82\%) patients. Improvement of EEG recording in patiets with hypsarrhytmia meant its withdrawal and, in other cases, reduction of paroxysmal changes and their amplitude and the dominance of slow theta and delta waves. A substantial reduction (75\%) in the frequency of seizures was present in five patients $(10 \%)$. Two of them were seizure-free after 2 weeks of treatment but had recurrence of seizures during a tapering-off period. In patients with genetic etiology, therapy was effective in $5 / 8(62.5 \%)$ patients. The treatment failed in one patient with 
tuberous sclerosis (TSC), one with a mitochondrial disease, and one with microdeletion 2q24.4. Efficacy in patients with structural etiology other than TSC was 17/20 (85\%). In this group, the treatment was effective in 10/11 patients (91\%) with HIE, 5/7 (72\%) with cerebral malformations, one patient with two possible causes of epilepsy, and one patient with postinfectious changes. In patients with unknown etiology, the therapy was effective in 20 patients (91\%), including all patients who could be classified as cryptogenic according to the previous ILAE classification. A total of $80.5 \%$ of patients previously classified as symptomatic had cessation of spasms. The differences between cryptogenic and symptomatic patients in the chi-square test were not statistically significant $(p=0.345)$ (using of terms symptomatic and cryptogenic, although not recommended by ILAE, allow for better comparison with previous study). There were also no statistically significant differences between the children with known and unknown etiology $(p=0.427)$. Gender did not have any influence on cessation of seizures $(p=0.501)$.

\subsection{Adverse Events during ACTH Treatment}

There was no case of death during ACTH therapy. The most common adverse events during treatment and taper were infections (respiratory tract, urinary system, gastrointestinal), $\mathrm{N}=26$ (52\%). Most of them were mild and did not have an impact on the epilepsy treatment. Antibiotics were used in 19 (38\%) patients. In six (12\%) patients, stereotyped dyskinesia (usually of the facial region: oral buccal) was observed. These movement disorders stopped gradually within a month of discontinuation of ACTH treatment. Arterial hypertension was present in five (10\%) patients. Hypertension had been diagnosed by cardiologist, who made the decision of temporary use of blood pressure-lowering drugs. In all patients, the blood pressure values returned to normal after completion of the steroid therapy.

Hypokalemia was noted in four $(8 \%)$ patients.

\subsection{Follow-Up}

Information on the clinical course of 28 patients was obtained during phone follow-up. The study was conducted between June and September 2017. We focused on the presence or absence of seizures (not only IS), drug therapy, and development.

The average follow-up was $37 \pm 24.4$ months. Table 5 shows the duration of follow-up.

Table 5. Duration of follow-up.

\begin{tabular}{cccccccc}
\hline $\begin{array}{c}\text { Length of Follow-Up Study } \\
\text { (Months) }\end{array}$ & $\mathbf{< 1 3}$ & $\mathbf{1 3 - 2 4}$ & $\mathbf{2 5 - 3 6}$ & $\mathbf{3 7 - 4 8}$ & $\mathbf{4 9 - 6 0}$ & $\mathbf{6 1 - 7 2}$ & $>\mathbf{7 2}$ \\
\hline Number of patients (\%) & $5(18)$ & $4(14)$ & $7(25)$ & $3(11)$ & $2(7)$ & $3(11)$ & $4(14)$ \\
\hline
\end{tabular}

In $17(60.7 \%)$ cases, seizures were still present. Among patients without seizures, six children were classified as cryptogenic, and five children (23\%) were recognized as symptomatic (three children were diagnosed with mitochondrial encephalopathy, one with neurofibromatosis type 1 , and one with microdeletion $2 \mathrm{q} 24.4$ ). There was not any significant difference related to gender $(p=1.0)$.

Twenty-seven children (97\%) were still on anti-epileptic therapy. Most commonly used were valproate, vigabatrin, and levetiracetam in 20,14, and 12 patients, respectively. Moreover, in 18 cases, valproate was in combination with other drugs: in 10 children, vigabatrin; in 8 cases, levetiracetam; in 3 cases, clobazam; in 3 cases, clonazepam; in 2 children, topiramate; and in 1 case, lacosamide.

Normal or near-normal development was observed in 11 out of 28 children (39\%).The clinical outcomes of all 28 cases and the comparison of symptomatic and cryptogenic patients are shown in Table 6. 
Table 6. Differences in follow-up between cryptogenic and symptomatic patients.

\begin{tabular}{cccc}
\hline & $\begin{array}{c}\text { Cryptogenic } \\
\text { Patients (\%) }\end{array}$ & $\begin{array}{c}\text { Symptomatic } \\
\text { Patients (\%) }\end{array}$ & $p$-Value \\
\hline Seizures & & & \\
absent & $6(100)$ & $5(23)$ & 0.001 \\
present: & 0 & $17(77)$ & \\
more than 2 per month & 0 & $11(50)$ & \\
less than 2 per month & 0 & $6(27)$ & \\
\hline AED & & & \\
absent & 0 & $1(5)$ & \\
monotherapy & $2(33)$ & $9(9)$ & 0.078 \\
2 drugs & $4(67)$ & $10(43)$ & \\
3 or more & 0 & $2.4 \mathrm{SD}=1.0$ & \\
Mean & $1.7 \mathrm{SD}=0.5$ & $16(73)$ & \\
\hline Development: & $1(17)$ & $6(27)$ & \\
unfavorable & $5(83)$ & & \\
favorable & & & \\
\hline
\end{tabular}

\section{Discussion}

The mechanism of action of ACTH is still unknown. Treatment with ACTH may reduce neuronal excitability by lowering the production and release of CRH and by directly affecting limbic neurons via melanocortin specific receptors, mainly MC1R and MC3R [1-12]. Randomized, controlled hormonal-treatment trials in West syndrome/epileptic spasms are shown in Table 7.

In this study, we present high short-term efficacy of ACTH used concomitantly with other AEDs in a group of patients with IS who did not achieve cessation of seizures or relapsed when taking other AEDs. Monitored adverse events were common (especially infections) but acceptable, and they did not require ACTH discontinuation. Dyskinesia occurred in six (12\%) patients. In follow-up, effects were better in cryptogenic patients.

Adverse events in randomized, controlled trials, in which at least one group used hormonal treatment, and were published after 2010 are listed in Table 7.

Using ACTH in polytherapy is an interesting approach, and some studies suggest that it can be more effective than monotherapy in infantile spasms treatment [18-20]. A randomized, multicenter, open-label trial provided evidence that hormonal therapy (tetracosactide, prednisolone) and vigabatrin are more effective than hormonal therapy alone during four weeks of observation [18]. A randomized, open-label study from China also suggested that ACTH in polytherapy with MgSO4 has a better effect than ACTH monotherapy in 24 weeks of follow-up [19]. Prospective study at Severance Children's Hospital also demonstrated the potential of a treatment protocol using polytherapy(vigabatrin and prednisolone) for West syndrome [20]. Other studies also showed that initial polytherapy with ACTH and other AED or topiramate followed by low-dose ACTH are effective and well-tolerated options in IS [21-23]; however, it is worth noting that the randomized, open-label, controlled trial denied the effectiveness of combination of hormonal therapy(prednisone) and moderate dose of to piramate [24].

In our study, short-term efficacy seems to be high in comparison with the results from randomized studies from the last ten years (Table 6) [18,19,24-34].

The number of patients with cessation of IS in our study is very similar to the groups using hormonal treatments in combination with other drugs [18-20,35]. Relatively good short-term efficacy of the add-on ACTH polytherapy in our study might be associated with cumulative effects of different drugs suggested by the previously mentioned studies, especially vigabatrin, which was taken by most patients [18-20,35]. Valproate was also commonly used in our study and might have had an important role in the reached outcome, but there are limited data about its efficacy in IS $[14,36]$. In addition, clobazam used in our study might be a potentially effective adjunctive drug for West syndrome [37]. It is 
worth mentioning that similar results were reached in some old studies in the case of highdose ACTH monotherapy and combination of low-dose ACTH and pyridoxine [23,38]. According to some authors, increasing the dose of ACTH does not necessarily result in better seizures control [39].

However, on the other hand, we would not favor polytherapy because of the risk of serious adverse effects (e.g., potential hepatotoxicity in infancy). There is also no proven evidence of effectiveness of polyteraphy in infantile spasms. Based on observation, we would like to stress that it is worthwhile to start ACTH even after refractory spasms and relapses and even after a long delay.

Monitored adverse events reported in this study were relatively mild, and they did not require discontinuation of treatment (Table 8).

Table 7. Randomized, controlled hormonal-treatment trials published after 2010.

\begin{tabular}{|c|c|c|c|c|}
\hline Study & Therapy & $\begin{array}{c}\text { No. } \\
\text { of Patients }\end{array}$ & Etiology & $\begin{array}{c}\text { Cessation of } \\
\text { Seizures Rate }(\%)\end{array}$ \\
\hline \multirow{2}{*}{ Zou 2010 [19] } & $\begin{array}{c}\text { ACTH } 25 \mathrm{U} / \mathrm{d} \text { and } \mathrm{MgSO}_{4} \\
0.25 \mathrm{~g} / \mathrm{kg} / \mathrm{d} \\
3 \text { weeks }\end{array}$ & 19 & $\begin{array}{l}\text { Cryp. } 3(16 \%) \\
\text { Symp. } 16(84 \%)\end{array}$ & $\begin{array}{c}\text { 1st week, } 42 \% \\
\text { 2nd week, 53\% } \\
\text { 4th week, 63\% } \\
\text { 8th week, } 79 \% \\
\text { 12th week, } 74 \% \\
\text { 24th week, 63\% }\end{array}$ \\
\hline & $\begin{array}{l}\text { ACTH } 25 \mathrm{U} / \mathrm{d} \\
3 \text { weeks }\end{array}$ & 19 & $\begin{array}{l}\text { Cryp. } 2(11 \%) \\
\text { Symp. } 17(89 \%)\end{array}$ & $\begin{array}{c}\text { 1st week 5\% } \\
\text { 2nd week } 21 \% \\
\text { 4th week } 42 \% \\
\text { 8th week } 53 \% \\
\text { 12th week, } 47 \% \\
\text { 24th week, } 53 \%\end{array}$ \\
\hline \multirow{2}{*}{$\begin{array}{l}\text { Chellamuthu et al., } 2014 \\
\text { [28] }\end{array}$} & $\begin{array}{l}\text { Oral prednisolone } \\
2 \mathrm{mg} / \mathrm{kg} / \mathrm{d}\end{array}$ & 32 & $\begin{array}{c}\text { Known, } 27(84 \%) \\
\text { Unknown, } 5(16 \%)\end{array}$ & 14 days, $25 \%$ \\
\hline & $\begin{array}{l}\text { Oral prednisolone } \\
4 \mathrm{mg} / \mathrm{kg} / \mathrm{d}\end{array}$ & 31 & $\begin{array}{l}\text { Known } 26(84 \%) \\
\text { Unknown } 5(16 \%)\end{array}$ & 14 days, $51.6 \%$ \\
\hline \multirow{2}{*}{$\begin{array}{c}\text { Wanigasinghe } 2015 \text { [29] } \\
\text { Wanigashingasighe } \\
\text { 2017 [30] }\end{array}$} & $\begin{array}{l}\text { Corticotropin } 0.5-0.75 \mathrm{mg} \\
(40 \mathrm{IU}) / 2 \mathrm{~d} \\
2 \text { weeks and taper }\end{array}$ & 49 & \multirow{2}{*}{$\begin{array}{l}\text { Known } 68 \% \\
\text { Unknown } 24 \% \\
\text { Incomplete } \\
\text { evaluation } 7 \%\end{array}$} & $\begin{array}{c}14 \text { days, } 37 \% \\
42 \text { days, } 41 \% \\
3 \text { months, } 39 \% \\
6 \text { months, } 45 \% \\
12 \text { months } 41 \%\end{array}$ \\
\hline & $\begin{array}{l}\text { Oral prednisolone } \\
\quad 40-60 \mathrm{mg} / \mathrm{d} \\
2 \text { weeks and taper }\end{array}$ & 48 & & $\begin{array}{c}14 \text { days, } 58 \% \\
42 \text { days, } 67 \% \\
3 \text { months, } 65 \% \\
6 \text { months, } 58 \% \\
12 \text { months, } 56 \%\end{array}$ \\
\hline \multirow[t]{2}{*}{$\begin{array}{l}\text { O'Callaghan et al., } 2017 \\
{[18]} \\
\text { O'Callaghan et al., } 2018 \\
{[31]}\end{array}$} & $\begin{array}{c}\text { Prednisolone } 40-60 \mathrm{mg} / \mathrm{d} \text { or } \\
\text { tetracosactide } \\
0.5-0.75 \mathrm{mg}(40 \mathrm{IU}) / 2 \mathrm{~d} \\
2 \text { weeks and taper } \\
\text { Vigabatrin } \\
50-150 \mathrm{mg} / \mathrm{kg} / \mathrm{d} \\
3 \text { months and taper }\end{array}$ & 186 & \multirow[t]{2}{*}{$\begin{array}{c}\text { Known, } 219(58 \%) \\
\text { Unknown, } 158(42 \%)\end{array}$} & $\begin{array}{c}14 \text { days } 89 \% \\
42 \text { days, } 72 \% \\
\text { At age } 18-19 \text { months, } \\
70 \%\end{array}$ \\
\hline & $\begin{array}{l}\text { Prednisolone } 40-60 \mathrm{mg} / \mathrm{d} \text { or } \\
\text { tetracosactide } 0.5-0.75 \mathrm{mg} \\
(40 \mathrm{IU}) / \mathrm{d} \\
2 \text { weeks and taper }\end{array}$ & 191 & & $\begin{array}{c}14 \text { days } 69 \% \\
42 \text { days, } 57 \% \\
\text { At age } 18-19 \text { months, } \\
71 \%\end{array}$ \\
\hline
\end{tabular}


Table 7. Cont.

\begin{tabular}{|c|c|c|c|c|}
\hline Study & Therapy & $\begin{array}{c}\text { No. } \\
\text { of Patients }\end{array}$ & Etiology & $\begin{array}{c}\text { Cessation of } \\
\text { Seizures Rate (\%) }\end{array}$ \\
\hline \multirow[b]{2}{*}{$\begin{array}{l}\text { Kunnanayaka V. } \\
2018 \text { [32] }\end{array}$} & Prednisolone $4 \mathrm{mg} / \mathrm{kg} / \mathrm{d}$ & 32 & $\begin{array}{l}\text { Known, } 27(84 \%) \\
\text { Unknown, } 5(16 \%)\end{array}$ & $\begin{array}{l}14 \text { days } 37.5 \% \\
1 \text { month, } 25 \%\end{array}$ \\
\hline & $\begin{array}{l}\text { Prednisolone } 4 \mathrm{mg} / \mathrm{kg} / \mathrm{d} \text { and } \\
\quad 30 \mathrm{mg} / \mathrm{kg} / \mathrm{d} \text { pyridoxine }\end{array}$ & 30 & $\begin{array}{c}\text { Known, } 26(86 \%) \\
\text { Unknown, } 4(14 \%)\end{array}$ & $\begin{array}{l}14 \text { days, } 37 \% \\
1 \text { month, } 33 \%\end{array}$ \\
\hline \multirow[b]{2}{*}{ ZhaoshiYi et al., 2019 [24] } & Prednisone $4 \times 10 \mathrm{mg} / \mathrm{d}^{\mathrm{a}}$ & 39 & $\begin{array}{c}\text { Known } 25(64.1 \%) \\
\text { Unknown } 14(35.9 \%)\end{array}$ & $\begin{array}{r}14 \text { days } 71.8 \% \\
120 \text { days } 61.5 \%\end{array}$ \\
\hline & $\begin{array}{l}\text { Prednisone } 4 \times 10 \mathrm{mg} / \mathrm{a} \text { and } \\
\text { TPM gradually titrated from } \\
1 \mathrm{mg} \text { to } 5 \mathrm{mg} \text { in } 14 \text { day } / \mathrm{kg} / \mathrm{d}^{\mathrm{b}}\end{array}$ & 38 & $\begin{array}{l}\text { Known } 23(60.5 \%) \\
\text { Unknown } 15(39.5 \%)\end{array}$ & $\begin{array}{r}14 \text { days } 76.3 \% \\
120 \text { days } 50.0 \%\end{array}$ \\
\hline \multirow{2}{*}{$\begin{array}{c}\text { Angappan et al., } 2019 \\
{[33]}\end{array}$} & $\begin{array}{c}\text { Tetracosactide } 30-60 \mathrm{IU} / \mathrm{d} \text {, } \\
\text { the dose increasing every } \\
2-3 \text { days by } 10 \mathrm{IU} \\
\text { and taper }\end{array}$ & 15 & $\begin{array}{c}\text { Structural } 12(80 \%) \\
\text { Non-structural } 3(10 \%)\end{array}$ & $\begin{array}{c}2 \text { weeks till } 6 \text { weeks } \\
40 \%\end{array}$ \\
\hline & $\begin{array}{l}\text { Oral zonisamide } \\
4-25 \mathrm{mg} / \mathrm{kg} / \text { day }\end{array}$ & 15 & Structural $100 \%$ & $\begin{array}{l}2 \text { weeks till } 6 \text { weeks } \\
27 \%\end{array}$ \\
\hline \multirow{2}{*}{ Gowda et al., 2019 [34] } & $\begin{array}{l}\text { ACTH } 100 \text { IU / body } \\
\text { surface area/d }\end{array}$ & 18 & $\begin{array}{l}\text { Symp } 14(77.77 \%) \\
\text { Idiop } 1(5.55 \%) \\
\text { Cryp. } 3(16.66 \%) \\
\end{array}$ & $\begin{array}{l}14 \text { days } 50 \% \\
28 \text { days } 61.11 \%\end{array}$ \\
\hline & $\begin{array}{c}\text { PRDL } 4 \mathrm{mg} / \mathrm{kg} / \mathrm{d} \text { for } \\
2 \text { weeks, then tapered over } \\
\text { 3-4 weeks) }\end{array}$ & 16 & $\begin{array}{l}\text { Symp } 13(81.25 \%) \\
\text { Idiop } 0(0 \%) \\
\text { Cryp. } 3(18.75 \%) \\
\end{array}$ & $\begin{array}{l}14 \text { days } 33.33 \% \\
28 \text { days } 40 \%\end{array}$ \\
\hline \multirow{2}{*}{ Dressler et al., 2019 [25] } & $\begin{array}{l}\mathrm{ACTH} 150 \mathrm{IU} / \mathrm{m}^{2} \text { for } \\
2 \text { weeks and taper }\end{array}$ & 16 & $\begin{array}{c}\text { Known } 11(69 \%) \\
\text { Unknown } 5(31 \%)\end{array}$ & 24 month $44 \%$ \\
\hline & Ketogenic diet & 16 & $\begin{array}{l}\text { Known } 7(44 \%) \\
\text { Unknown } 8(66 \%)\end{array}$ & 24 month $38 \%$ \\
\hline \multirow{2}{*}{ Fayyazzi et al., 2020 [26] } & АСТН $0.1 \mathrm{mg} / \mathrm{d}$ & 16 & \multirow{2}{*}{$\begin{array}{l}\text { Known } 25(78 \%) \\
\text { Structural } 17(53 \%) \\
\text { Unknown } 7(22 \%)\end{array}$} & c \\
\hline & АСТН $0.25 \mathrm{mg} / \mathrm{d}^{\mathrm{d}}$ & 16 & & c \\
\hline \multirow{2}{*}{$\begin{array}{c}\text { Imannezhad et al., } 2020 \\
\text { [27] }\end{array}$} & $\begin{array}{c}\text { ACTH } 5 \times 2-3 \mathrm{IU} / \mathrm{kg} / \mathrm{d} \\
(\text { max: } 100 \mathrm{IU})\end{array}$ & 25 & \multirow{2}{*}{ N.A. } & 14 days $69.2 \%$ \\
\hline & $\begin{array}{l}\text { Prednisolone } 8 \mathrm{mg} / \mathrm{kg} / \mathrm{d} \\
\text { (max: } 60 \mathrm{mg} \text { ) }\end{array}$ & 26 & & 14 days $76 \%$ \\
\hline
\end{tabular}

${ }^{a}$ If spasm still occurred on day 7 , the dose was changed; it reached $15 \mathrm{mg}$ once and was kept at this level for the next 14 days, four times each day. Whether the spasms hadstopped or not, after these 14 days, the dose of prednisone was decreased every week until completing a 49-day or 56-day course (e.g., $40 \mathrm{mg}$ one time a day for a week or $30 \mathrm{mg}$ one time a day for a week, $20 \mathrm{mg}$ one time a day for a week, $10 \mathrm{mg}$ one time a day for a week, $5 \mathrm{mg}$ one time a day for a week, and finally, $5 \mathrm{mg}$ every two days for a week). ${ }^{\mathrm{b}}$ Additionally, the combination therapy group used TPM at an initial dose of $1 \mathrm{mg} / \mathrm{kg} /$ day twice a day, then gradually increased it to $3 \mathrm{mg} / \mathrm{kg} / \mathrm{day}$ on day 7 and $5 \mathrm{mg} / \mathrm{kg} /$ day on day $14 .{ }^{\mathrm{c}}$ No further medications were needed at the end of the therapeutic protocol since symptoms, such as convulsions and spasm, were fully controlled in $18.7 \%$ of patients. Apart from ACTH, another medicine was given to $5.37 \%$ of patients to fully control the convulsions. Using another drug helped $25 \%$ of patients with controlling, to some extent, theoccurring convulsions and spasms. The mentioned symptoms were resistant to treatment in $3.9 \%$ of patients despite concomitant treatment with ACTH and several other drugs. There was no significant change in any of the four levels defined for controlling spasms and convulsions. ${ }^{\mathrm{d}}$ The method of ACTH administration: 1st week, one time a day; 2nd week, once every second day; 3rd week, two times a week; 4th week, one weekly; and 5th to 8th week, once every two weeks. Increase daily dose if the patient was not responsive after two weeks; 14 days of therapy, and then, the dose was tapered off over the remaining two weeks. ${ }^{\mathrm{e}}$ A dose of $8 \mathrm{mg} / \mathrm{kg}$ /day of prednisolone (max: $60 \mathrm{mg}$ ) was administrated to patients who belonged to the corticosteroid group. It was used for three weeks, divided into three doses. Later, the dose was decreased in responders. Two weeks later, non-responders were given $2-3 \mathrm{U} / \mathrm{kg} /$ day of ACTH (max: $100 \mathrm{U}$ ) for five days. If the patients did not show signs of improvement within two weeks of treatment, they were planned to receive intramuscular biologic ACTH immediately after the failure of corticosteroid therapy. The patients received five daily doses of 2-3 IU / kg of ACTH (max: $100 \mathrm{IU}$ ), and the treatment was then changed to the oral corticosteroid. In the second group (25 patients), patients first received five daily doses of $2-3 \mathrm{IU} / \mathrm{kg}$ of ACTH. 
Table 8. Adverse events in randomized, controlled trials, in which at least one group used hormonal treatment, and were published after 2010, which were found in bases PubMed, Google Scholar, and Embase. Studies about including patients without IS are not presented in the table.

\begin{tabular}{|c|c|c|c|c|}
\hline \multirow{2}{*}{ Study } & \multicolumn{2}{|c|}{ Therapy 1} & \multicolumn{2}{|c|}{ Therapy 2} \\
\hline & Adverse Events & No $(\%)$ & Adverse Events & No $(\%)$ \\
\hline \multirow{10}{*}{ Zou 2010 [19] } & \multicolumn{2}{|c|}{$\begin{array}{c}\text { ACTH } 25 \mathrm{U} / \mathrm{d} \text { and } \mathrm{MgSO} 40.25 \mathrm{~g} / \mathrm{kg} / \mathrm{d} \\
\text { 3 weeks } \\
(19)^{*}\end{array}$} & \multicolumn{2}{|c|}{$\begin{array}{l}\text { ACTH } 25 \mathrm{U} / \mathrm{d} \\
3 \text { weeks } \\
(19) *\end{array}$} \\
\hline & Pyrexia & $3(15.8)$ & Pyrexia & $3(15.8)$ \\
\hline & $\begin{array}{l}\text { Upper respiratory } \\
\text { tract infection }\end{array}$ & $3(15.8)$ & $\begin{array}{l}\text { Upper respiratory } \\
\text { tract infection }\end{array}$ & $3(15.8)$ \\
\hline & Diarrhea & $2(10.5)$ & Diarrhea & $2(10.5)$ \\
\hline & Anorexia & $1(5.3)$ & Anorexia & $1(5.3)$ \\
\hline & Vomiting & $0(0)$ & Vomiting & $1(5.3)$ \\
\hline & Hypertension & $2(10.5)$ & Hypertension & $0(0)$ \\
\hline & Insomnia & $2(10.5)$ & Insomnia & $0(0)$ \\
\hline & Irritability & $2(10.5)$ & Irritability & $0(0)$ \\
\hline & $\begin{array}{l}\text { Decreased heart rate, } \\
\text { prolonged PR interval }\end{array}$ & $1(5.3)$ & $\begin{array}{l}\text { Decreased heart rate, } \\
\text { prolonged PR interval }\end{array}$ & $0(0)$ \\
\hline \multirow{9}{*}{$\begin{array}{l}\text { Chellamuth et al., } 2014 \\
\text { [28] }\end{array}$} & \multicolumn{2}{|c|}{$\begin{array}{l}\text { Oral prednisolone } 2 \mathrm{mg} / \mathrm{kg} / \mathrm{d} \\
(32)^{*}\end{array}$} & \multicolumn{2}{|c|}{$\begin{array}{l}\text { Oral prednisolone } 4 \mathrm{mg} / \mathrm{kg} / \mathrm{d} \\
\qquad(31)^{*}\end{array}$} \\
\hline & Weight gain & $4(12.5)$ & Weight gain & $9(29)$ \\
\hline & Hypertension & $1(3.12)$ & Hypertension & $0(0)$ \\
\hline & Cushingoid facies & $7(22.6)$ & Cushingoid facies & $13(41.9)$ \\
\hline & Infections & $6(18.7)$ & Infections & $9(29)$ \\
\hline & Irritability & $3(9.4)$ & Irritability & $2(6.5)$ \\
\hline & Increased appetite & $2(6.3)$ & Increased appetite & $4(12.9)$ \\
\hline & Glycosuria & $0(0)$ & Glycosuria & $0(0)$ \\
\hline & Others & $2(6.3)$ & Others & $1(3)$ \\
\hline \multirow{12}{*}{$\begin{array}{l}\text { Wanigasinghe } 2015 \text { [29] } \\
\text { Wanigassighe } 2017 \text { [30] }\end{array}$} & \multicolumn{2}{|c|}{$\begin{array}{l}\text { Oral prednisolone } \\
40-60 \mathrm{mg} / \mathrm{d} \\
2 \text { weeks and taper } \\
(48)^{*}\end{array}$} & \multicolumn{2}{|c|}{$\begin{array}{c}\text { Tetracosactide } \\
0.5-0.75 \mathrm{mg}(40 \mathrm{IU}) / 2 \mathrm{~d} \\
2 \text { weeks and taper } \\
(49)^{*}\end{array}$} \\
\hline & Increased appetite & $28(73.7)$ & Increased appetite & $19(43.2)$ \\
\hline & Weight gain & $19(50)$ & Weight gain & $14(31.8)$ \\
\hline & Frequent crying spells & $16(42.1)$ & Frequent crying spells & $11(25)$ \\
\hline & Drowsiness & $4(10.5)$ & Drowsiness & $7(15.9)$ \\
\hline & Cushingoid features & $8(21.1)$ & Cushingoid features & $9(20.5)$ \\
\hline & Insomnia & $3(7.9)$ & Insomnia & $2(4.5)$ \\
\hline & Lethargy & $2(5.3)$ & Lethargy & $2(4.5)$ \\
\hline & $\begin{array}{l}\text { Reduction in } \\
\text { social behavior }\end{array}$ & $2(5.3)$ & $\begin{array}{l}\text { Reduction in } \\
\text { social behavior }\end{array}$ & $1(2.3)$ \\
\hline & Abdominal distension & $8(21.1)$ & Abdominal distension & $0(0)$ \\
\hline & Hypertension & $1(2.6)$ & Hypertension & $1(2.3)$ \\
\hline & $\begin{array}{l}\text { Increased susceptibility } \\
\text { to infection }\end{array}$ & $0(0)$ & $\begin{array}{l}\text { Increased susceptibility } \\
\text { to infection }\end{array}$ & $1(2.3)$ \\
\hline
\end{tabular}


Table 8. Cont.

\begin{tabular}{|c|c|c|c|c|}
\hline \multirow{2}{*}{ Study } & \multicolumn{2}{|c|}{ Therapy 1} & \multicolumn{2}{|c|}{ Therapy 2} \\
\hline & Adverse Events & No $(\%)$ & Adverse Events & No $(\%)$ \\
\hline & Irritability & $8(21.1)$ & Irritability & 5 (11.4) \\
\hline & Nausea & $1(2.6)$ & Nausea & $1(2.3)$ \\
\hline & Vomiting & $2(5.3)$ & Vomiting & $1(2.3)$ \\
\hline & Diarrhea & $2(5.3)$ & Diarrhea & $3(6.8)$ \\
\hline & Dyspepsia & $2(5.3)$ & Dyspepsia & $2(4.5)$ \\
\hline & Electrolyte imbalances & $2(5.3)$ & Electrolyte imbalances & $0(0)$ \\
\hline \multirow{23}{*}{$\begin{array}{l}\text { O'Callaghan et al., } \\
2017 \text { [18] } \\
\text { O'Callaghan et al., } \\
2018 \text { [31] }\end{array}$} & \multicolumn{2}{|c|}{$\begin{array}{c}\text { Prednisolone } 40-60 \mathrm{mg} / \mathrm{d} \text { or } \\
\text { tetracosactide } 0.5-0.75 \mathrm{mg}(40 \mathrm{IU}) / \mathrm{d} \\
2 \text { weeks and taper } \\
(191) *\end{array}$} & \multicolumn{2}{|c|}{$\begin{array}{c}\text { Prednisolone } 40-60 \mathrm{mg} / \mathrm{d} \text { or } \\
\text { tetracosactide } 0.5-0.75 \mathrm{mg}(40 \mathrm{IU}) / 2 \mathrm{~d} \\
2 \text { weeks and taper } \\
\text { Vigabatrin } 50-150 \mathrm{mg} / \mathrm{kg} / \mathrm{d} \\
3 \text { months and taper } \\
(186) *\end{array}$} \\
\hline & $\begin{array}{l}\text { Allergic rash or } \\
\text { anaphylaxis }\end{array}$ & $1(1)$ & $\begin{array}{l}\text { Allergic rash or } \\
\text { anaphylaxis }\end{array}$ & $0(0)$ \\
\hline & Drowsiness & $3(2)$ & Drowsiness & $45(24)$ \\
\hline & $\begin{array}{c}\text { Endocrine or } \\
\text { metabolic disturbance }\end{array}$ & $2(1)$ & $\begin{array}{c}\text { Endocrine or } \\
\text { metabolic disturbance }\end{array}$ & $1(1)$ \\
\hline & $\begin{array}{l}\text { Fluid or } \\
\text { electrolyte disturbance }\end{array}$ & $23(12)$ & $\begin{array}{c}\text { Fluid or } \\
\text { electrolyte disturbance }\end{array}$ & $12(6)$ \\
\hline & Gastrointestinal upset & $26(14)$ & Gastrointestinal upset & $23(12)$ \\
\hline & Hypertonia & $9(5)$ & Hypertonia & $3(2)$ \\
\hline & Hypotonia & $8(4)$ & Hypotonia & $7(4)$ \\
\hline & Immunosuppression & $3(2)$ & Immunosuppression & $3(2)$ \\
\hline & Increased appetite & $51(27)$ & Increased appetite & $35(19)$ \\
\hline & Infection & $19(10)$ & Infection & $14(8)$ \\
\hline & Irritability & $75(39)$ & Irritability & $61(33)$ \\
\hline & $\begin{array}{l}\text { Neuropsychiatric } \\
\text { (disturbed sleep) }\end{array}$ & $35(18)$ & $\begin{array}{l}\text { Neuropsychiatric } \\
\text { (disturbed sleep) }\end{array}$ & $29(16)$ \\
\hline & $\begin{array}{l}\text { Varicella zoster } \\
\text { (chicken pox) }\end{array}$ & $4(2)$ & $\begin{array}{l}\text { Varicella zoster } \\
\text { (chicken pox) }\end{array}$ & $2(1)$ \\
\hline & Weight gain & $34(18)$ & Weight gain & $24(13)$ \\
\hline & $\begin{array}{l}\text { Abnormal eye } \\
\text { movements }\end{array}$ & $0(0)$ & Abnormal eye movements & $1(1)$ \\
\hline & $\begin{array}{c}\text { Blood disorder } \\
\text { (high platelet count) }\end{array}$ & $0(0)$ & $\begin{array}{c}\text { Blood disorder } \\
\text { (high platelet count) }\end{array}$ & $1(1)$ \\
\hline & Bradycardia & $0(0)$ & Bradycardia & $1(1)$ \\
\hline & $\begin{array}{l}\text { Abnormal breathing } \\
\text { pattern }\end{array}$ & $1(1)$ & $\begin{array}{l}\text { Abnormal breathing } \\
\text { pattern }\end{array}$ & $0(0)$ \\
\hline & $\begin{array}{l}\text { High MRI signal in } \\
\text { basal ganglia }\end{array}$ & $1(1)$ & $\begin{array}{l}\text { High MRI signal in } \\
\text { basal ganglia }\end{array}$ & $2(1)$ \\
\hline & Hypoxia & $1(1)$ & Hypoxia & $0(0)$ \\
\hline & Movement disorder & $2(1)$ & Movement disorder & $14(8)$ \\
\hline & Not focusing (vision) & $0(0)$ & Not focusing (vision) & $1(1)$ \\
\hline
\end{tabular}


Table 8. Cont.

\begin{tabular}{|c|c|c|c|c|}
\hline \multirow{2}{*}{ Study } & \multicolumn{2}{|c|}{ Therapy 1} & \multicolumn{2}{|c|}{ Therapy 2} \\
\hline & Adverse Events & No $(\%)$ & Adverse Events & No $(\%)$ \\
\hline & $\begin{array}{l}\text { Obstructive cardiac } \\
\text { hypertrophy }\end{array}$ & $1(1)$ & $\begin{array}{l}\text { Obstructive cardiac } \\
\text { hypertrophy }\end{array}$ & $0(0)$ \\
\hline & Pallor & $1(1)$ & Pallor & $0(0)$ \\
\hline & Squinting & $1(1)$ & Squinting & $0(0)$ \\
\hline & Sweating & $1(1)$ & Sweating & $1(1)$ \\
\hline & Tachypnoea & $1(1)$ & Tachypnoea & $0(0)$ \\
\hline \multirow{7}{*}{$\begin{array}{c}\text { Kunnanayaka V } 2018 \\
\text { [32] }\end{array}$} & \multicolumn{2}{|c|}{$\begin{array}{l}\text { Prednisolone } 4 \mathrm{mg} / \mathrm{kg} / \mathrm{d} \\
\qquad(32) *\end{array}$} & \multicolumn{2}{|c|}{$\begin{array}{c}\text { Prednisolone } 4 \mathrm{mg} / \mathrm{kg} / \mathrm{d} \text { and } 30 \mathrm{mg} / \mathrm{kg} / \mathrm{d} \\
\text { pyridoxine } \\
(30)^{*}\end{array}$} \\
\hline & Increased appetite & $25(78)$ & Increased appetite & $24(75)$ \\
\hline & Irritability & $19(59)$ & Irritability & $12(40)$ \\
\hline & $\begin{array}{l}\text { Excessive daytime } \\
\text { sleepiness }\end{array}$ & $21(66)$ & $\begin{array}{l}\text { Excessive daytime } \\
\text { sleepiness }\end{array}$ & $20(67)$ \\
\hline & Cushingoid facies & $5(16)$ & Cushingoid facies & $4(13)$ \\
\hline & Oral ulcers & $4(13)$ & Oral ulcers & $6(20)$ \\
\hline & Weight gain & $5(16)$ & Weight gain & $4(13)$ \\
\hline \multirow{8}{*}{$\begin{array}{l}\text { ZhaoshiYi et al., } 2019 \\
\text { [24] }\end{array}$} & \multicolumn{2}{|c|}{$\begin{array}{l}\text { Prednisone } 4 \times 10 \mathrm{mg} / \mathrm{d} \\
(39) *\end{array}$} & \multicolumn{2}{|c|}{$\begin{array}{c}\text { Prednisone } 4 \times 10 \mathrm{mg} / \text { and TPM gradually } \\
\text { titrated from } 1 \mathrm{mg} \text { to } 5 \mathrm{mg} \text { in } 14 \text { day } / \mathrm{kg} / \mathrm{d} \\
(38)^{*}\end{array}$} \\
\hline & Cushing's symptoms & $34(87.2 \%)$ & Cushing's symptoms & $32(84.2)$ \\
\hline & Increased appetite & 35 (89.7) & Increased appetite & $29(76.3)$ \\
\hline & Irritability & $18(46.2)$ & Irritability & $12(31.6)$ \\
\hline & Drowsiness & $8(20.5)$ & Drowsiness & $7(18.4)$ \\
\hline & Intercurrent infection & $11(28.2)$ & Intercurrent infection & $12(31.6)$ \\
\hline & Hypertension & $1(2.6)$ & Hypertension & $0(0.0)$ \\
\hline & Sleep disturbance & $9(23.1)$ & Sleep disturbance & $7(18.4)$ \\
\hline \multirow{7}{*}{$\begin{array}{c}\text { Angappan et al., } 2019 \\
{[33]}\end{array}$} & \multicolumn{2}{|c|}{$\begin{array}{c}\text { Tetracosactide } 30-60 \mathrm{IU} / \mathrm{d} \text {, the dose increasing } \\
\text { every } 2-3 \text { days by } 10 \mathrm{IU} \text { and taper } \\
(15)^{*}\end{array}$} & \multicolumn{2}{|c|}{$\begin{array}{l}\text { Oral zonisamide } 4-25 \mathrm{mg} / \mathrm{kg} / \text { day } \\
\qquad(15) *\end{array}$} \\
\hline & Hypertension & $14(93.3)$ & Lethargy & 8 \\
\hline & Weight gain & $5(33.3)$ & Irritability & $5(33.3)$ \\
\hline & Cushingoid faces & $3(20)$ & Gastroenteritis & $2(13.3)$ \\
\hline & Irritability & $3(20)$ & $\begin{array}{l}\text { Dryness of skin } \\
\text { and mouth }\end{array}$ & $1(6.7)$ \\
\hline & Infection & $2(13.3)$ & Loss of appetite & $1(6.7)$ \\
\hline & Hyperpigmentation & $1(6.7)$ & Metabolic acidosis & $1(6.7)$ \\
\hline \multirow[t]{2}{*}{ Gowda et al., 2019 [34] } & \multicolumn{2}{|c|}{$\begin{array}{c}\text { ACTH } 100 \text { IU / body surface area /d } \\
(18)^{*}\end{array}$} & \multicolumn{2}{|c|}{$\begin{array}{c}\text { PRDL } 4 \mathrm{mg} / \mathrm{kg} / \mathrm{d} \text { for } 2 \text { weeks, then tapered } \\
\text { over } 3-4 \text { weeks) } \\
(16)^{*}\end{array}$} \\
\hline & Side effects in general & $3(16.6)$ & Side effects in general & $3(20)$ \\
\hline
\end{tabular}


Table 8. Cont.

\begin{tabular}{|c|c|c|c|c|}
\hline \multirow{2}{*}{ Study } & \multicolumn{2}{|c|}{ Therapy 1} & \multicolumn{2}{|c|}{ Therapy 2} \\
\hline & Adverse Events & No $(\%)$ & Adverse Events & No $(\%)$ \\
\hline \multirow{19}{*}{ Dressler et al., 2019 [25] } & \multicolumn{2}{|c|}{$\begin{array}{l}\text { ACTH } 150 \mathrm{IU} / \mathrm{m} 2 \text { a } 2 \text { weeks and taper } \\
\qquad(48)^{*}\end{array}$} & \multicolumn{2}{|c|}{$\begin{array}{l}\text { Ketogenic diet } \\
\quad(53) *\end{array}$} \\
\hline & Adverse effects overall & $45(94)$ & Adverse effects overall & $42(79)$ \\
\hline & $\begin{array}{l}\text { Needing acute } \\
\text { intervention }\end{array}$ & $45(94)$ & $\begin{array}{c}\text { Needing acute } \\
\text { intervention }\end{array}$ & $16(30)$ \\
\hline & Hypertonia & $41(85)$ & High triglycerides & $16(30)$ \\
\hline & Potassium (intravenous) & $19(40)$ & Obstipation & 14 \\
\hline & Cushing syndrome & $17(35)$ & Ketones > $5 \mathrm{mmol} \mathrm{L}^{-1}$ & 13 \\
\hline & Cardiac hypertrophy & $16(33)$ & Solid food refusal & 9 \\
\hline & Leukocytosis & $16(33)$ & Liquids (intravenous) & 7 \\
\hline & Infections & $14(29)$ & Infections & $6(11)$ \\
\hline & Hyperexcitability & $12(25)$ & Diarrhea & $6(11)$ \\
\hline & Acne & $12(25)$ & High cholesterol & $5(9)$ \\
\hline & Weight gain & $11(23)$ & Growth deficit & $5(9)$ \\
\hline & Drowsiness & $8(17)$ & Cholecystolithiasis & $5(9)$ \\
\hline & Edema & $8(17)$ & Tiredness at start & $3(6)$ \\
\hline & - & - & Hypoglycemia & $3(6)$ \\
\hline & - & - & Carnitine deficiency & $3(6)$ \\
\hline & - & - & Weight loss & $3(6)$ \\
\hline & - & - & Refusal of KD liquids & $3(6)$ \\
\hline & - & - & Weight gain & $1(2)$ \\
\hline \multirow{2}{*}{$\begin{array}{l}\text { Fayyazzi et al., } 2020 \\
\text { [26] }\end{array}$} & \multicolumn{2}{|c|}{$\begin{array}{l}\mathrm{ACTH} \\
(16) *\end{array}$} & \multicolumn{2}{|c|}{$\begin{array}{l}\text { ACTH } 0.25 \mathrm{mg} / \mathrm{d} \\
(16) *\end{array}$} \\
\hline & N.A & N.A & N.A & N.A \\
\hline \multirow{2}{*}{$\begin{array}{c}\text { Imannezhad et al., } 2020 \\
\text { [27] }\end{array}$} & \multicolumn{2}{|c|}{$\begin{array}{c}\mathrm{ACTH} 5 \times 2-3 \mathrm{IU} / \mathrm{kg} / \mathrm{d}(\max : 100 \mathrm{IU}) \\
(25)^{*}\end{array}$} & \multicolumn{2}{|c|}{$\begin{array}{l}\text { Prednisolone } 8 \mathrm{mg} / \mathrm{kg} / \mathrm{d}(\max : 60 \mathrm{mg}) \\
(26) *\end{array}$} \\
\hline & N.A & N.A & N.A & N.A \\
\hline
\end{tabular}

${ }^{*}$ Number of patient

Dyskinesia is a newly reported side effect of hormonal treatment. In this study, six $(12 \%)$ patients had a dyskinesia similar to that previously reported [40,41]. Many patients in this study took vigabatrin, and movement disorders might be also potentially associated with vigabatrin [42,43]. In ICISS, the group treated with the combination of hormonal therapy and vigabatrin had higher rate of movement disorders than the group taking hormonal therapy alone [18]. In ten investigated patients enrolled in ICISS, eight of them had movement disorders after initiation of vigabatrin, but they resolved after vigabatrin withdrawal only in two patients. Seven of them also took hormonal treatment during the onset of the movement disorders [42]. Due to the ICISS report, mentioned movement disorders were not linked to vigabatrin, and they were likely caused by an underlying neurological disease [18].

In our study, the number of patients with a developmental delay and seizures in a long-term perspective was significantly lower in cryptogenic patients, which is consistent with previous studies [8-12,31]. In total, 39\% of them were seizure free, and among them, all were cryptogenic patients $(100 \%)$, and $22.7 \%$ were symptomatic patients. This result resembles long-term outcome in other studies; however, some treatment options used in 
the studies presented in the Table 6 resulted in better long-term outcome, which can be caused by differences in methodology and time of observation [11,19,25-27,29,30,33,34,44]. Cryptogenic patients seem to have slightly better and symptomatic slightly worse seizure outcome than patients from UKISS and the observational multicenter Belgian study by Mert et al. [10-12]. Development was normal or near normal in 39\% of patients-83\% cryptogenic and $27 \%$ symptomatic patients. According to the meta-analysis and systematic review published in $2015,54.3 \%$ of cryptogenic and $12.5 \%$ of symptomatic patients with IS had normal or near-normal developmental outcome [9]. In the context of these data, the developmental outcome in our study seems to be good. On the other hand, there is a possibility that assessment of development was stricter in other studies. Shorter time to treatment results in better developmental outcome, especially in cryptogenic patients [8,9,31,45]. Good developmental outcome among cryptogenic patients in our study might be also associated with short lead time to treatment in this group of patients.

It should be mentioned that according to the latest meta-analysis, high-dose prednisolone is not inferior to adrenocorticotrophic hormone [46,47]; indeed, ACTH is less cost-effective, defined as probability of clinical spasm resolution 14 days after treatment initiation, than oral prednisolone (in the United States) [48].

Our study has some weakness and limitations. The first is a partially retrospective character. Others are an inaccessibility of almost half of patients for follow-up and differences in time of follow-up for particular patients. The follow-up method, phone interview, might be less accurate than direct clinical assessment. The study did not assess some ACTH adverse events. This study is not a clinical trial but only a description of experience from our clinic. There was not a control group, so it does not allow for making an accurate comparison for different used drugs or approaches in infantile spasms treatment; it only assesses effectiveness of the add-on ACTH therapy in this group of patients.

\section{Conclusions}

ACTH used concomitantly with other AED is a highly effective treatment with acceptable side effects. In accordance with other studies, the long-term outcome was better throughout cryptogenic patients. Randomized, controlled, clinical trials with long-term follow-up are needed to compare effectiveness of ACTH in polytherapy and monotherapy. Dyskinesias as a potential side effect observed in our study group should be investigated in future studies.

Author Contributions: Conceptualization, J.P.; methodology, J.P.; J.M.; V.P.-M.; B.N.; M.K.; software, J.P.; J.M.; V.P.-M.; B.N.; M.K.; validation, J.P.; J.M.; V.P.-M.; B.N.; M.K.; formal analysis, J.P.; J.M.; V.P.-M.; B.N.; M.K.; investigation, J.P.; J.M.; V.P.-M.; B.N.; M.K.; resources, J.P.; J.M.; V.P.-M.; B.N.; M.K.; data curation, J.P.; J.M.; V.P.-M.; B.N.; M.K.; writing—original draft preparation, J.P.; J.M.; V.P.-M.; B.N.; M.K.; writing—review and editing, J.P.; J.M.; V.P.-M.; B.N.; M.K.; visualization, J.P.; J.M.; V.P.-M.; B.N.; M.K.; supervision, J.P.; I.K.; project administration, J.P.; funding acquisition, J.P. All authors have read and agreed to the published version of the manuscript.

Funding: This research received no external funding.

Institutional Review Board Statement: The study was conducted according to the guidelines of the Declaration of Helsinki.

Informed Consent Statement: Informed consent was obtained from all subjects involved in the study.

Data Availability Statement: The data analyzed during the current study are available from the corresponding author on reasonable request.

Conflicts of Interest: The authors declare no conflict of interest. 


\section{References}

1. Fois, A. Infantile spasms: Review of the literature and personal experience. Ital. J. Pediatr. 2010, 36, 15. [CrossRef] [PubMed]

2. Wilmshurst, J.M.; Gaillard, W.D.; Vinayan, K.P.; Tsuchida, T.N.; Plouin, P.; Van Bogaert, P.; Carrizosa, J.; Elia, M.; Craiu, D.; Jovic, N.J.; et al. Summary of recommendations for the management of infantile seizures: Task Force Report for the ILAE Commission of Pediatrics. Epilepsia 2015, 56, 1185-1197. [CrossRef] [PubMed]

3. Lux, A.L.; Osborne, J.P. A proposal for case definitions and outcome measures in studies of infantile spasms and West syndrome: Consensus statement of the West Delphi Group. Epilepsia 2004, 45, 1416-1428. [CrossRef] [PubMed]

4. Wilmshurst, J.M.; Ibekwe, R.C.; O'Callaghan, F.J.K. Epileptic spasms-175 years on: Trying to teach an old dog new tricks. Seizure 2017, 44, 81-86. [CrossRef]

5. Wheless, J.W.; Gibson, P.A.; Rosbeck, K.L.; Hardin, M.; O’Dell, C.; Whittemore, V.; Pellock, J.M. Infantile spasms (West syndrome) Update and resources for pediatricians and providers to share with parents. BMC Pediatr. 2012, 12, 108. [CrossRef]

6. Rudzka-Dybała, M.; Szczepanik, E.; Terczyńska, I. Patterns of the EEG records in children with West Syndrome. Przegl. Lek. 2015, 72, 694-696.

7. Proposal for Revised Classification of Epilepsies and Epileptic Syndromes. Epilepsia 1989, 30, 389-399. [CrossRef]

8. Lux, A.L.; Edwards, S.W.; Hancock, E.; Johnson, A.L.; Kennedy, C.R.; Newton, R.W.; O'Callaghan, F.J.K.; Verity, C.M.; Osborne, J.P. The United Kingdom Infantile Spasms Study (UKISS) comparing hormone treatment with vigabatrin on developmental and epilepsy outcomes to age 14 months: A multicentre randomised trial. Lancet Neurol. 2005, 4, 712-717. [CrossRef]

9. Widjaja, E.; Go, C.; McCoy, B.; Snead, O.C. Neurodevelopmental outcome of infantile spasms: A systematic review and meta-analysis. Epilepsy Res. 2015, 109, 155-162. [CrossRef]

10. Gul Mert, G.; Herguner, M.O.; Incecik, F.; Altunbasak, S.; Sahan, D.; Unal, I. Risk factors affecting prognosis in infantile spasm. Int. J. Neurosci. 2017, 127, 1012-1018. [CrossRef]

11. Darke, K.; Edwards, S.W.; Hancock, E.; Johnson, A.L.; Kennedy, C.R.; Lux, A.L.; Newton, R.W.; O'Callaghan, F.J.K.; Verity, C.M.; Osborne, J.P. Developmental and epilepsy outcomes at age 4 years in the UKISS trial comparing hormonal treatments to vigabatrin for infantile spasms: A multi-centre randomised trial. Arch. Dis. Child. 2010, 95, 382-386. [CrossRef] [PubMed]

12. Lagae, L.; Verhelst, H.; Ceulemans, B.; De Meirleir, L.; Nassogne, M.C.; De Borchgrave, V.; D’Hooghe, M.; Foulon, M.; Van Bogaert, P. Treatment and long term outcome in West syndrome: The clinical reality. A multicentre follow up study. Seizure 2010, 19, 159-164. [CrossRef] [PubMed]

13. Scheffer, I.E.; Berkovic, S.; Capovilla, G.; Connolly, M.B.; French, J.; Guilhoto, L.; Hirsch, E.; Jain, S.; Mathern, G.W.; Moshé, S.L.; et al. ILAE classification of the epilepsies: Position paper of the ILAE Commission for Classification and Terminology. Epilepsia 2017, 58, 512-521. [CrossRef] [PubMed]

14. Song, J.M.; Hahn, J.; Kim, S.H.; Chang, M.J. Efficacy of treatments for infantile spasms: A systematic review. Clin. Neuropharmacol. 2017, 40, 63-84. [CrossRef]

15. Iyer, A.; Appleton, R. Improving Outcomes in Infantile Spasms: Role of Pharmacotherapy. Pediatr. Drugs 2016, 18, 357-366. [CrossRef]

16. Knupp, K.G.; Coryell, J.; Nickels, K.C.; Ryan, N.; Leister, E.; Loddenkemper, T.; Grinspan, Z.; Hartman, A.L.; Kossoff, E.H.; Gaillard, W.D.; et al. Response to treatment in a prospective national infantile spasms cohort. Ann. Neurol. 2016, 79, 475-484. [CrossRef]

17. Demarest, S.T.; Shellhaas, R.A.; Gaillard, W.D.; Keator, C.; Nickels, K.C.; Hussain, S.A.; Loddenkemper, T.; Patel, A.D.; Saneto, R.P.; Wirrell, E.; et al. The impact of hypsarrhythmia on infantile spasms treatment response: Observational cohort study from the National Infantile Spasms Consortium. Epilepsia 2017, 58, 2098-2103. [CrossRef]

18. O'Callaghan, F.J.K.; Edwards, S.W.; Alber, F.D.; Hancock, E.; Johnson, A.L.; Kennedy, C.R.; Likeman, M.; Lux, A.L.; Mackay, M.; Mallick, A.A.; et al. Safety and effectiveness of hormonal treatment versus hormonal treatment with vigabatrin for infantile spasms (ICISS): A randomised, multicentre, open-label trial. Lancet Neurol. 2017, 16, 33-42. [CrossRef]

19. Zou, L.P.; Wang, X.; Dong, C.H.; Chen, C.H.; Zhao, W.; Zhao, R.Y. Three-week combination treatment with ACTH + magnesium sulfate versus ACTH monotherapy for infantile spasms: A 24-week, randomized, open-label, follow-up study in China. Clin. Ther. 2010, 32, 692-700. [CrossRef]

20. Ko, A.; Youn, S.E.; Chung, H.J.; Kim, S.H.; Lee, J.S.; Kim, H.D.; Kang, H.C. Vigabatrin and high-dose prednisolone therapy for patients with West syndrome. Epilepsy Res. 2018, 145, 127-133. [CrossRef]

21. Jia, F.Y.; Jiang, H.Y.; Du, L.; Li, N.; Sun, J.; Niu, C.B. An effective initial polytherapy for children with West syndrome. Neural Regen. Res. 2013, 8, 1623-1630. [CrossRef] [PubMed]

22. Zhu, X.; Chen, O.; Zhang, D.; Jin, R.; Li, F.; Wang, Y.; Sun, R. A prospective study on the treatment of infantile spasms with first-line topiramate followed by low-dose ACTH. Epilepsy Res. 2011, 93, 149-154. [CrossRef] [PubMed]

23. Takuma, Y.; Seki, T. Combination therapy of infantile spasms with high-dose pyridoxal phosphate and low-dose corticotropin. J. Child Neurol. 1996, 11, 35-40. [CrossRef] [PubMed]

24. Yi, Z.; Wu, H.; Yu, X.; Zha, J.; Chen, H.; Chen, Y.; Zhong, J. High-dose prednisone therapy for infantile spasms and late-onset epileptic spasms in China: The addition of topiramate provides no benefit. Seizure 2019, 71, 174-178. [CrossRef]

25. Dressler, A.; Benninger, F.; Trimmel-Schwahofer, P.; Gröppel, G.; Porsche, B.; Abraham, K.; Mühlebner, A.; Samueli, S.; Male, C.; Feucht, M. Efficacy and tolerability of the ketogenic diet versus high-dose adrenocorticotropic hormone for infantile spasms: A single-center parallel-cohort randomized controlled trial. Epilepsia 2019, 60, 441-451. [CrossRef] 
26. Fayyazi, A.; Eslamian, R.; Khajeh, A.; Dehghani, M. Comparison of the effect of high and low doses of adrenocorticotropic hormone (Acth) in the management of infantile spasms. Iran. J. Child Neurol. 2020, 14, 17-25. [CrossRef]

27. Imannezhad, S.; Akhondian, J.; Ashrafzadeh, F.; Toosi, M.B.; Hahemi, N.; Emadzadeh, M.; Akhondian, M.R. A Single-center Randomized Clinical Trial Comparing the Treatment Efficacy of High Dose Oral Prednisolone with Intramuscular Adrenocorticotropic Hormone in Patients with Infantile Spasm. Int. J. Pediatr. 2020, 8, 12157-12163. [CrossRef]

28. Chellamuthu, P.; Sharma, S.; Jain, P.; Kaushik, J.S.; Seth, A.; Aneja, S. High dose ( $4 \mathrm{mg} / \mathrm{kg} /$ day) versus usual dose (2 mg/kg/day) oral prednisolone for treatment of infantile spasms: An open-label, randomized controlled trial. Epilepsy Res. 2014, 108, 1378-1384. [CrossRef]

29. Wanigasinghe, J.; Arambepola, C.; Sri Ranganathan, S.; Sumanasena, S.; Attanapola, G. Randomized, single-blind, parallel clinical trial on efficacy of oral prednisolone versus intramuscular corticotropin on immediate and continued spasm control in west syndrome. Pediatr. Neurol. 2015, 53, 193-199. [CrossRef]

30. Wanigasinghe, J.; Arambepola, C.; Ranganathan, S.S.; Sumanasena, S. Randomized, Single-Blind, Parallel Clinical Trial on Efficacy of Oral Prednisolone Versus Intramuscular Corticotropin: A 12-Month Assessment of Spasm Control in West Syndrome. Pediatr. Neurol. 2017, 76, 14-19. [CrossRef]

31. O'Callaghan, F.J.K.; Edwards, S.W.; Alber, F.D.; Cortina Borja, M.; Hancock, E.; Johnson, A.L.; Kennedy, C.; Likeman, M.; Lux, A.L.; Mackay, M.T.; et al. Vigabatrin with hormonal treatment versus hormonal treatment alone (ICISS) for infantile spasms: 18-month outcomes of an open-label, randomised controlled trial. Lancet Child Adolesc. Health 2018, 2, 715-725. [CrossRef]

32. Kunnanayaka, V.; Jain, P.; Sharma, S.; Seth, A.; Aneja, S. Addition of pyridoxine to prednisolone in the treatment of infantile spasms: A pilot, randomized controlled trial. Neurol. India 2018, 66, 385-390. [CrossRef] [PubMed]

33. Angappan, D.; Sahu, J.K.; Malhi, P.; Singhi, P. Safety, tolerability, and effectiveness of oral zonisamide therapy in comparison with intramuscular adrenocorticotropic hormone therapy in infants with West syndrome. Eur. J. Paediatr. Neurol. 2019, $23,136-142$. [CrossRef] [PubMed]

34. Gowda, V.K.; Narayanaswamy, V.; Shivappa, S.K.; Benakappa, N.; Benakappa, A. Corticotrophin-ACTH in Comparison to Prednisolone in West Syndrome-A Randomized Study. Indian J. Pediatr. 2019, 86, 165-170. [CrossRef]

35. Knupp, K.G.; Leister, E.; Coryell, J.; Nickels, K.C.; Ryan, N.; Juarez-Colunga, E.; Gaillard, W.D.; Mytinger, J.R.; Berg, A.T.; Millichap, J.; et al. Response to second treatment after initial failed treatment in a multicenter prospective infantile spasms cohort. Epilepsia 2016, 57, 1834-1842. [CrossRef]

36. Pavone, P.; Polizzi, A.; Marino, S.D.; Corsello, G.; Falsaperla, R.; Marino, S.; Ruggieri, M. West syndrome: A comprehensive review. Neurol. Sci. 2020, 41, 3547-3562. [CrossRef]

37. Hahn, J.; Lee, H.; Kang, H.C.; Lee, J.S.; Kim, H.D.; Kim, S.H.; Chang, M.J. Clobazam as an adjunctive treatment for infantile spasms. Epilepsy Behav. 2019, 95, 161-165. [CrossRef]

38. Baram, T.Z.; Mitchell, W.G.; Tournay, A.; Snead, O.C.; Hanson, R.A.; Horton, E.J. High-dose corticotropin (ACTH) versus prednisone for infantile spasms: A prospective, randomized, blinded study. Pediatrics 1996, 97, 375-379. [CrossRef]

39. Ito, M.; Okuno, T.; Fujii, T.; Mutoh, K.; Oguro, K.; Shiraishi, H.; Shirasaka, Y.; Mikawa, H. ACTH therapy in infantile spasms: Relationship between dose of ACTH and initial effect or long-term prognosis. Pediatr. Neurol. 1990, 6, 240-244. [CrossRef]

40. Sukhudyan, B.G.; Dimova, P.S.; Capuano, A.; Vigevano, F. Dyskinesia as a new adverse effect of hormonal treatment in West syndrome. Epileptic Disord. 2014, 16, 5-12. [CrossRef]

41. Arita, J.H.; Vale, T.C.; Pedroso, J.L.; Faria, E.C.; Arita, F.N.; Masruha, M.R.; Barsottini, O.G.P. ACTH-induced dyskinesia in a child with West syndrome (infantile spasms). Park. Relat. Disord. 2016, 24, 145-146. [CrossRef] [PubMed]

42. Fong, C.Y.; Osborne, J.P.; Edwards, S.W.; Hemingway, C.; Hancock, E.; Johnson, A.L.; Kennedy, C.R.; Kneen, R.; Likeman, M.; Lux, A.L.; et al. An investigation into the relationship between vigabatrin, movement disorders, and brain magnetic resonance imaging abnormalities in children with infantile spasms. Dev. Med. Child Neurol. 2013, 55, 862-867. [CrossRef] [PubMed]

43. Schonstedt, V.; Stecher, X.; Venegas, V.; Silva, C. Vigabatrin-induced MRI changes associated with extrapyramidal symptoms in a child with infantile spasms. Neuroradiol. J. 2015, 28, 515-518. [CrossRef] [PubMed]

44. Lux, A.L.; Edwards, S.W.; Hancock, E.; Johnson, A.L.; Kennedy, C.R.; Newton, R.W.; O'Callaghan, F.J.K.; Verity, C.M.; Osborne, J.P. The United Kingdom Infantile Spasms Study comparing vigabatrin with prednisolone or tetracosactide at 14 days: A multicentre, randomised controlled trial. Lancet 2004, 364, 1773-1778. [CrossRef]

45. O'Callaghan, F.J.K.; Lux, A.L.; Darke, K.; Edwards, S.W.; Hancock, E.; Johnson, A.L.; Kennedy, C.R.; Newton, R.W.; Verity, C.M.; Osborne, J.P. The effect of lead time to treatment and of age of onset on developmental outcome at 4 years in infantile spasms: Evidence from the United Kingdom Infantile Spasms Study. Epilepsia 2011, 52, 1359-1364. [CrossRef]

46. Chang, Y.H.; Chen, C.; Chen, S.H.; Shen, Y.C.; Kuo, Y.T. Effectiveness of corticosteroids versus adrenocorticotropic hormone for infantile spasms: A systematic review and meta-analysis. Ann. Clin. Transl. Neurol. 2019, 6, 2270-2281. [CrossRef]

47. Li, S.; Zhong, X.; Hong, S.; Li, T.; Jiang, L. Prednisolone/prednisone as adrenocorticotropic hormone alternative for infantile spasms: A meta-analysis of randomized controlled trials. Dev. Med. Child Neurol. 2020, 62, 575-580. [CrossRef]

48. Sánchez Fernández, I.; Amengual-Gual, M.; Gaínza-Lein, M.; Barcia Aguilar, C.; Bergin, A.M.; Yuskaitis, C.J.; Harini, C. Cost-effectiveness of adrenocorticotropic hormone versus oral steroids for infantile spasms. Epilepsia 2021, 62, 347-357. [CrossRef] 